\title{
Vulnerabilities of Southwestern U.S. Rangeland-based animal agriculture to climate change
}

\author{
K. M. Havstad ${ }^{1}$ • J. R. Brown ${ }^{2}$ • R. Estell ${ }^{1}$ • E. Elias ${ }^{1}$ • \\ A. Rango $^{1} \cdot$ C. Steele ${ }^{1}$
}

Received: 29 April 2016/Accepted: 6 October 2016 /Published online: 8 November 2016

(C) The Author(s) 2016. This article is published with open access at Springerlink.com

\begin{abstract}
The Southwestern US is a five-state region that has supported animal agriculture since the late 16th Century when European settlers crossed the Rio Grande into present day west Texas and southern New Mexico with herds of cattle, sheep, goats and horses. For the past 400 years the rangeland livestock industry, in its many forms and manifestations, has developed management strategies and conservation practices that impart resilience to the climatic extremes, especially prolonged droughts, that are common and extensive across this region. Livestock production from rangelands in the southwest (SW) is adapted to low rainfall and high ambient temperatures, but will have to continue to adapt management strategies, such as reduced stocking rates, proper grazing management practices, employing animal genetics suited to arid environments with less
\end{abstract}

This article is part of a Special Issue on 'Vulnerability of Regional Forest and Agricultural Ecosystems to a Changing Climate (USDA Southwest Climate Hub)’ edited by David Gutzler and Connie Maxwell

\section{K. M. Havstad}

Kris.Havstad@ars.usda.gov

\section{J. R. Brown}

joelbrow@nmsu.edu

R. Estell

Rick.Estell@ars.usda.gov

E. Elias

Emile.Elias@ars.usda.gov
A. Rango
Al.Rango@ ars.usda.gov
C. Steele
csteele@nmsu.edu

1 USDA Agricultural Research Service, Rangeland Management Research Unit based at the Jornada Experimental Range, NMSU, MSC 3JER, PO Box 30003, Las Cruces, NM 88003, USA

2 Soil Science Division, Ecological Sites National Leader, USDA Natural Resource Conservation Service, NMSU, MSC 3JER, PO Box 30003, Las Cruces, NM 88003, USA 
herbaceous production, erosion control conservation practices, and alternative forage supplies, in an increasingly arid and variable climatic environment. Even though the aging demographics of western ranchers could be a deterrent to implementing various adaptations, there are examples of creative management coalitions to cope with climatic change that are emerging in the SW that can serve as instructive examples. More importantly, there are additional opportunities for incorporation of transformative practices and technologies that can sustain animal agriculture in the SW in a warmer environment. Animal agriculture in the SW is inherently resilient, and has the capacity to adapt and transform as needed to the climatic changes that are now occurring and will continue to occur across this region. However, producers and land managers will need to thoroughly understand the vulnerabilities and sensitivities that face them as well as the ecological characteristics of their specific landscapes in order to cope with the emerging climatic changes across the SW region.

\section{Introduction}

Animal agriculture accounts for approximately one-third of the total agricultural revenue in the Southwest (SW) region of the U.S. (USDA 2013). In 2012, the market value of livestock and poultry for the five-state region of California, Arizona, Nevada, Utah and New Mexico, the Southwestern US, was \$17.6B. Approximately $70 \%$ of livestock revenues in this region are from beef cattle and calves, and dairy cattle (USDA 2013). Beef cattle, as well as goats and sheep within the SW, are primarily raised on rangelands and pastures and these rangelandbased production systems are susceptible to the elevated temperatures and climatic extremes of a changing SW climate. Rangeland-based animal agriculture across this five-state SW region is the focus of this synthesis of knowledge about likely vulnerabilities and sensitivities for this industry with emerging regional climatic changes.

There are two unique features of rangeland-based animal agriculture in the SW region: 1) much of the resource is public land and managed by public land agencies including the Bureau of Land Management (BLM) and the US Forest Service (USFS), and 2) ranching enterprises across the region have vastly different capacities and characteristics that will influence their abilities to adapt to novel climatic conditions. This intermingling of private and federal grazing resources complicates livestock management across the SW region. Although access to federal land can provide additional forage resources to complement private land resources, the multiple use goals of federal land management agencies can complicate if not conflict with the long-term planning and short-term implementation of grazing management practices of public land rancher permittees. Resolving those conflicting goals presents both opportunities and challenges to both ranchers and public land managers and increases the complexity of responding to climate change.

Animal agriculture was first introduced into the SW by European settlers early in the 16th Century, but the rangeland livestock industry did not expand significantly until the late 19th Century with well-recognized, ecologically devastating impacts during this early period of livestock expansion (Bowling 1942; Sayre et al. 2012). Management principles and conservation practices for sustainable rangeland livestock production were established during the later half of the 20th Century (USDA NRCS 1997). However, though there have been several extended, severe drought periods over the last millennium (for example, see Fig. 3 in Peters et al. 2015), there is really no analogous climatic period during this brief history of animal agriculture that mirrors projected climatic change across the SW in the coming decades. 
The focal point of this review, and the challenge to successful future policies in general, should be on vulnerabilities of rangeland-based animal agriculture to climatic change rather than any specific consequences of particular anticipated changes. Though socioeconomic factors will play a role in this industry's capacities to cope with these vulnerabilities, such as a likely reduced capacity of a less experienced, next generation of ranchers in preparing for climate change, this review will primarily focus on climate change vulnerabilities. For example, it is anticipated that the region will experience a decrease in annual net primary plant productivity through the 21 st Century (Reeves et al. 2014). This will reduce available forages for overall livestock grazing capacities, and the need for animal agriculture to implement increasingly flexible management practices will be a key for economically (and ecologically) adapting to increasingly arid conditions (Torell 2010).

There are four primary pathways in animal production in which climate change is expected to affect animal agriculture in the SW: 1) feed-grain production, availability, and price, 2) rangeland, pasture and forage crop production and quality, 3) animal health, growth, and reproduction, and 4) disease and pest distributions. Of these four pathways, the first two dealing with feed and forage production are likely the most immediately vulnerable to climate change (Elias et al. 2015).

Given the importance of regional climate and ecological capacities of land to these pathways in animal production, this review will be based on the 2 dominant Land Resource Regions for grazing livestock that are contained almost entirely within the five states of California, Arizona, Nevada, Utah and New Mexico (Fig. 1). Land Resource Regions (LRR) are defined by the Natural Resource Conservation Service (NRCS) as a group of geographically associated land resource areas that approximate broad agricultural regions within the nation (USDA 2006). There are 28 LRRs across the conterminous US. Within each LRR are Major Land Resource

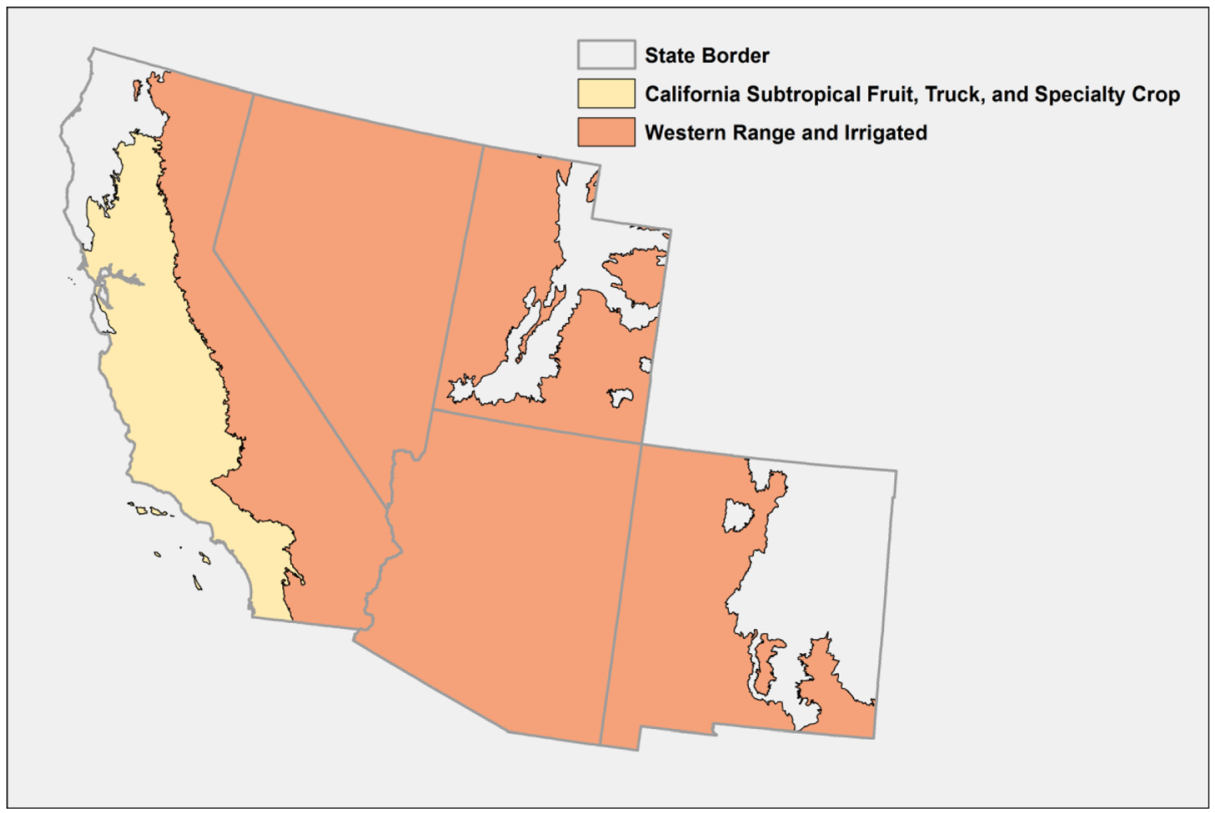

Fig. 1 The Western Range and Irrigated Land Resource Region (LRR) and the California Subtropical Fruit, Truck, and Specialty Crop LRR within the 5 states of California, Nevada, Arizona, Utah and New Mexico of the Southwestern US (USDA 2006). 
Areas (MLRA) defined as large areas of geographically associated and similar land resource units. There are 278 MLRAs in the US. The LRR and MLRA designations are useful in describing regions of broadly similar climate, landforms, geology and land use that characterize different regions of the nation. The two dominant LRRs in the southwestern US, the Western Range and Irrigated Land region and the California Subtropical Fruit, Truck and Specialty Crop region, comprise over $83 \%$ of the total land area of the SW. There are segments of four additional LRRs within the SW region, but these are primarily within adjacent regions of either the Pacific Northwest or the Southern Great Plains, and of minor importance within the SW. However, the regional vulnerabilities to climatic change discussed in this review would have general application to the portions of these LRRs within the SW region.

Of additional utility are ecological sites, defined as distinctive kinds of land with specific soil and physical characteristics that differ from other kinds of land in the ability to produce a distinctive kind and amount of vegetation and the ability to respond similarly to both natural disturbances and land management practices (USDA NRCS 1997). Ecological sites are the basic component within an MLRA that describes both a site's ecological dynamics and its ecological potential. Any specific MLRA can have a few to a few dozen ecological sites, and these sites are thoroughly described and characterized within the NRCS's Ecological Site Inventory System (USDA 2014). Impacts of climate change will be variable across the SW region, or any region, both because of the heterogeneity of how climate change will occur spatially, but also because the impacts of climate change may also be sensitive to the ecological characteristics of any specific landscape, e.g., an ecological site or groupings of ecological sites.

\section{The principal land resource regions in the SW}

\subsection{The western range and irrigated land resource region}

The Western Range and Irrigated LRR occurs primarily between the Sierra Nevada Mountains on the west side of this LRR to the Rocky Mountains on the east (Fig. 1). The LRR completely encompasses Arizona and Nevada, and comprises major portions of Utah, New Mexico and California. This LRR is $\sim 104 \mathrm{M}$ ha $\left(\sim 550,000 \mathrm{mi}^{2}\right)$, and includes the Great Basin Cold Desert and the three hot deserts of the SW US - the Mohave, Sonoran and Chihuahuan Deserts (USDA 2006).

Animal agriculture in this LRR is characterized by highly diverse beef cow-calf operations typical of western range livestock production, especially given the prominence of public lands within this LRR (USGS 2016; Fig. 2). A cow-calf operation is one in which the focus is production each year of a calf from each cow which is then sold after weaning from the cow at about 6 months of age. Annual revenues for 2012 from beef cattle operations by counties within the 21 MLRAs across this LRR are displayed in Fig. 3a (USDA 2013). There are approximately 20,000-25,000 ranches across this LRR, and the majority are ranches with $<100$ cows. Recent and historic economic analyses of ranching within this LRR repeatedly document low returns on investment with ranch values strongly influenced by acreage of the ranch rather than cow herd sizes. Production revenues are characteristically diverse as well. Beef cow generated revenues in 2012 varied from $<\$ 8 \mathrm{M}$ in counties within the Mohave Desert (MLRA 30) to $>\$ 30 \mathrm{M}$ in counties of the Great Salt Lake Area (MLRA 28A). Fourteen counties occurring within nine MLRAs of this LRR generated annual beef cattle revenues in excess of $\$ 16 \mathrm{M}$ for 2012. Irrigation water, which is typically drawn from surface water sources 


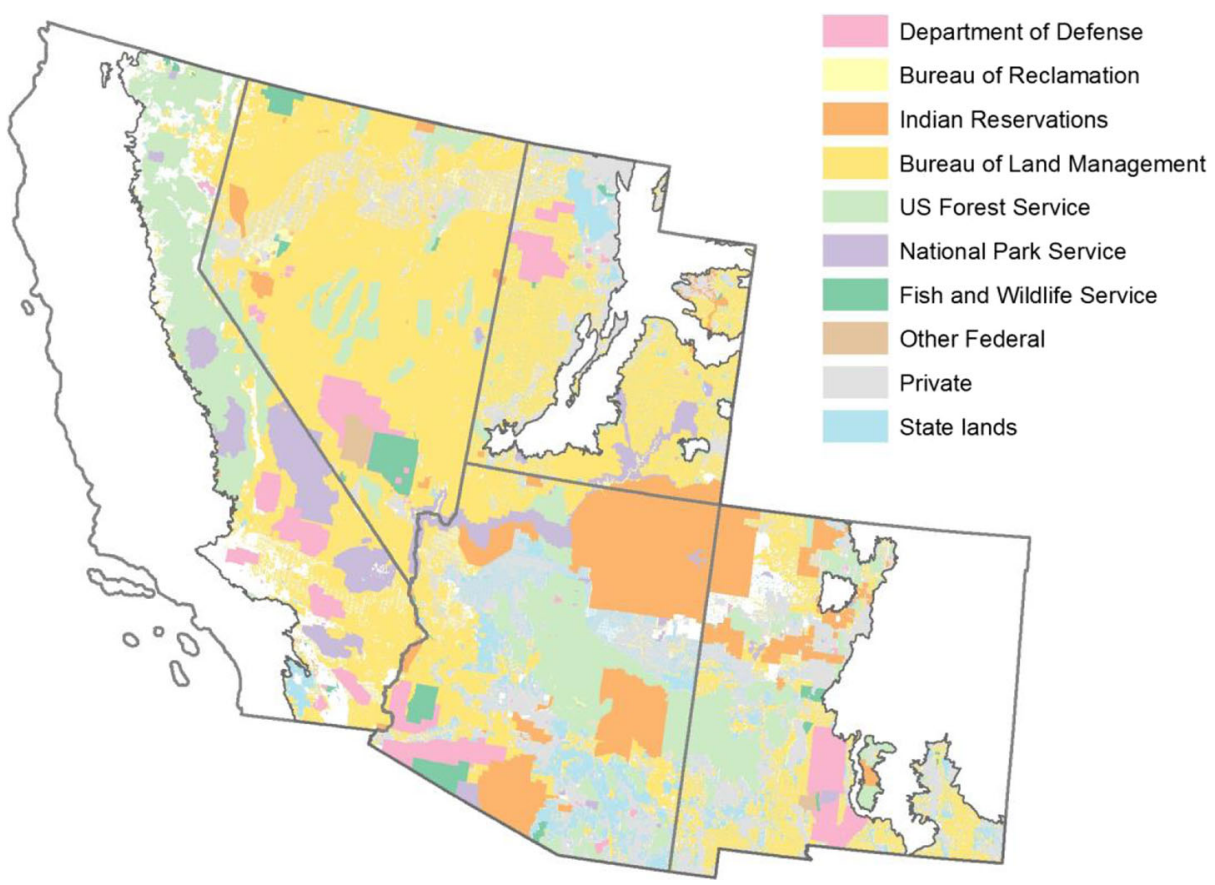

Fig. 2 Public land areas within the $1.42 \mathrm{M} \mathrm{km}^{2}$ Western Range and Irrigated Land Resource Region of the Southwestern US (USGS 2016).

and represents the primary use of water within the LRR (total withdrawals of fresh water in this LRR are $>30,025$ million gallons per day), is principally used to grow animal feed crops. Only one MLRA in the region (MLRA 41 in SE Arizona) draws irrigation water primarily from ground water sources. Given that $60 \%$ of this LRR is public land, livestock production is closely aligned to private lands where irrigated agriculture produces the needed harvested feeds and forages to periodically support beef cow-calf operations during any given year. For example, annual beef cow revenues exceed \$100 M within MLRA 28A that spans Beaver County in southwestern Utah to Cache County in north central Utah. About $60 \%$ of this MLRA is federal land, primarily managed by the BLM and the USFS. Livestock grazing use of these public lands, as is typical across the Western Range LRR, has declined in recent years (Fig. 4a). However, $27 \%$ of MLRA 28A is private crop and pasture lands used in support of livestock production. Higher livestock revenues within this MLRA are assumed to be directly linked to private land forage production that augments permits for public land grazing.

Similar observations can be drawn from livestock revenue within MLRA 42 of south central New Mexico. This arid region (150-250 mm annual precipitation) within the northern Chihuahuan Desert has low livestock grazing capacities due to its inherently low rangeland forage production. Annual forage production is also highly variable because of frequent and prolonged droughts. Consequently, beef cow-calf operations in MLRA 42 rely upon highly flexible stocking rates in response to these extreme annual variations in rainfall and forage production. To illustrate, Fig. 4b presents the annual use and non-use of the permitted 660,000 Animal Unit Months (AUMs)/year from 2002 to 2011 for the $2.2 \mathrm{M}$ ha of the BLM's Las Cruces Grazing District of southern NM within MLRA 42. An AUM serves as the unit for billing of permittees for livestock use of public rangeland, and is defined as the amount of 

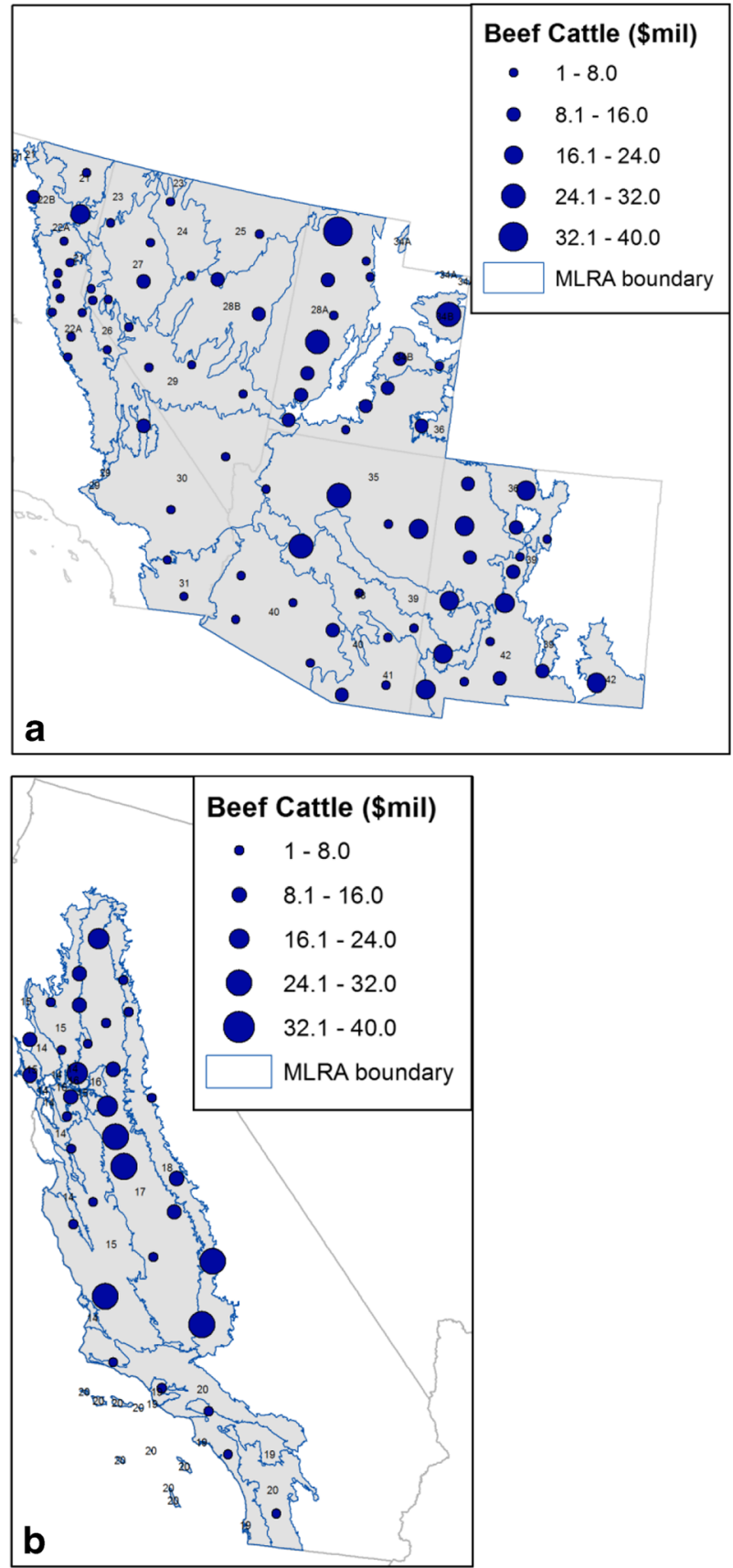

Fig. 3 a Beef cattle annual revenue for 2012 reported by county within the 21 Major Land Resource Areas (MLRAs; designated by their NRCS reference numbers 21-42) for the Western Range and Irrigated Land Resource Region (LRR) within California, Arizona, Nevada, Utah and New Mexico (USDA 2013). Locations of filled circles represent geographic centers of the 79 counties within these 5 states that are entirely or principally within this LRR, and $\mathbf{b}$ beef cattle annual revenue for 2012 reported by county within the 7 MLRAs (designated by their NRCS reference numbers 14-20) for the California Subtropical Fruit, Truck, and Specialty Crop LRR (USDA 2013). Locations of filled circles represent geographic centers of the 33 counties that are entirely or principally within this LRR. 
forage required to support the nutrient requirements of a mature cow or cow with a calf for 30 days. The permitted AUM level reflects the long term livestock grazing capacity for this BLM district with an average stocking rate of $\sim 3.2$ ha/AUM for th is specific grazing district. Between 2002 and 2011 actual annual use of permitted AUMs varied between $50 \%$ and $79 \%$ as beef cattle operators and the BLM restricted annual use given the vagaries of annual forage production. Concomitant with these annual variations is the importance of hay production on private irrigated cropland within the Middle Rio Grande River basin that dissects MLRA 42. Regionally available harvested forages from irrigated croplands are an important synergy to beef cow-calf operations even in the more arid regions of the southern portion of this LRR.

Vulnerabilities of ranchers and their ranching enterprises to an increasingly arid climate across this LRR are strongly shaped by their adaptive management capacities, sensitivities of the environment to impending climatic changes, and availability of needed forage resources. Key characteristics within this LRR that will influence the extent of these vulnerabilities are:

- Diverse beef cow-calf operations in predominantly arid and semi-arid environments,

- Prominence of public land rangeland grazing permits,

- Importance of harvested forages supplies during winter seasons or drought periods, or both,

- Inherently low rangeland forage productivity, and

- Highly variable annual forage production that is often low due to prolonged drought.

\subsection{The California subtropical fruit, truck, and specialty crop land resource region}

The California Subtropical Fruit, Truck, and Specialty Crop LRR (California LRR) comprises $\sim 16 \mathrm{M}$ ha $\left(\sim 64,000 \mathrm{mi}^{2}, \sim 1 / 8\right.$ th the size of the Western Range LRR) from the western California coast to the foothills of the Sierra Nevada Mountains on the east. Beef cattle production in this LRR is common within all seven regional MLRAs and in $90 \%$ of the counties in the LRR. In contrast to the Western Range LRR only $16 \%$ of the region is public land and ground water supplies $46 \%$ of the fresh water demand. Prominent landscapes in this LRR for animal agriculture are the central California pasture lands and rangelands in and adjacent to the Sacramento and San Joaquin Valleys (USDA 2006).

The majority of annual beef cattle revenues are generated from counties in the northern half of the LRR either entirely or primarily within three MLRAs (15,17, and 18; Fig. 3b). These three MLRAs total $\sim 11.5 \mathrm{M}$ ha $(\sim 72 \%$ of the California LRR), of which $\sim 4.8 \mathrm{M}$ ha are rangeland $(\sim 30 \%$ of the California LRR). Also, these three MLRAs include $\sim 2.7 \mathrm{M}$ ha of crop lands, and grain production is common on the non-irrigated crop lands. The majority of the grazed forage within the LRR supplied to the rangeland livestock industry originates from the $\sim 4.3 \mathrm{M}$ ha of annual grass-dominated rangelands and the $\sim 2 \mathrm{M}$ ha of hardwood forest that support a grassland understory. Most of this land is privately owned. However, rangeland livestock production at a ranch scale is often an amalgamation of deeded, leased, non-federal public and federal public lands. Access to federal public land at higher elevations can be essential for supporting grazing operations during the drier summer months. Livestock grazing in California is the state's most extensive type of land use, yet livestock production is just one ecosystem good within a set of goods and services derived from these rangelands (Huntsinger and Bartolome 2014). Cow-calf production systems are typically complemented by stocker operations (young, weaned light-weight calves placed on forage-based systems until they gain enough weight to be placed in feedlots or used as young replacement cows for 
a

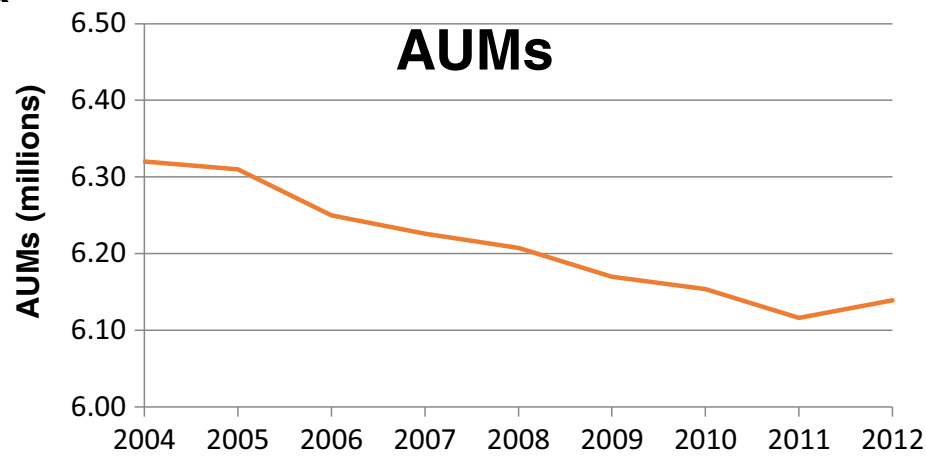

b Las Cruces District Office Summary of Authorized Use 2002-2011 by Grazing Fee Year

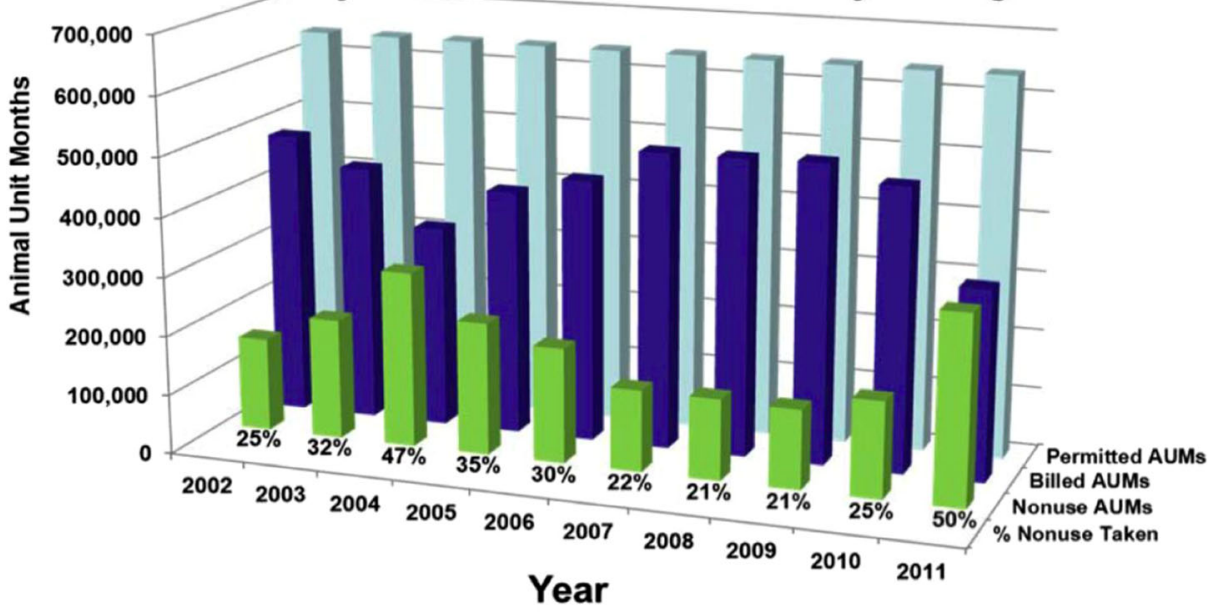

C

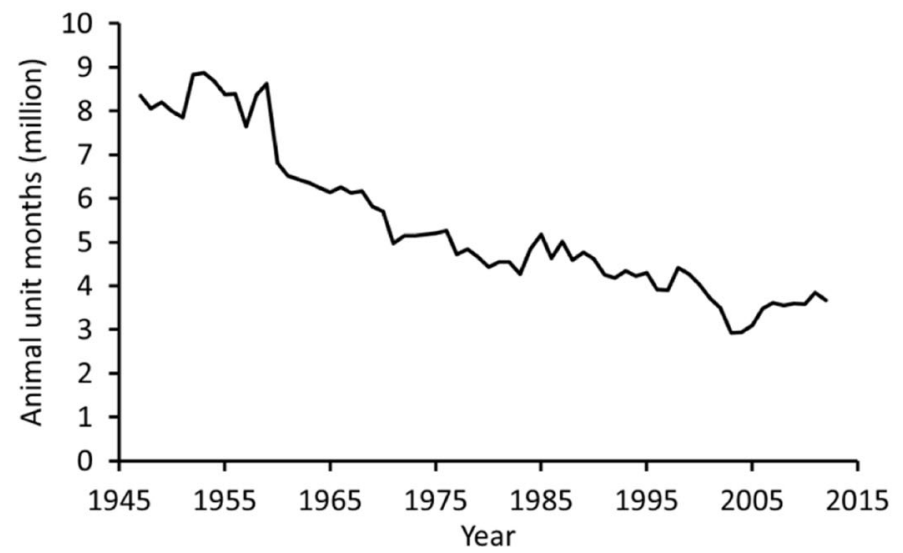

beef herds), sheep ( $\sim 300,000$ ewes), or goats ( 140,000 including dairy). There are $\sim 1 \mathrm{M}$ head of stocker cattle grazing annually on California rangelands. Many ranchers support their enterprises 
Fig. 4 a Decline in Animal Unit Months (AUMs; the unit of billing for livestock use of public rangelands, and represents one mature cow, with calf, for 30 days) used on all Bureau of Land Management (BLM) administered public lands within the Western Range and Irrigated Land Resource Region of California, Nevada, Arizona, Utah and New Mexico between 2004 and 2012 (USDI 2013), b actual annual billed use and resulting non-use of permitted AUMs from BLM administered rangelands within the 2.2 M ha Las Cruces Grazing District of southern New Mexico between 2002 and 2011 (USDI 2011), and c change in billed AUMs from 1947 to 2011 for all BLM managed lands in the states ofCalifornia, Nevada, Arizona, Utah and New Mexico (USDI 2013).

with other non-agricultural income sources or off-ranch employment. As in the Western Range LRR, ranch values are greatly influenced by land base values rather than animal production, and the use of conservation easements to extract financial benefits from ranchland is increasingly employed to maintain ranching operations. Conversion of rangeland to other land uses has been a consistent and growing pressure on the livestock industry (Huntsinger and Bartolome 2014).

\section{Regional vulnerabilities or susceptibilities}

Vulnerability has been defined as the extent to which a system may be damaged by climatic change (McCarthy et al. 2001). This differs from the definition of sensitivity, positive or negative, to a system by the impacts of climatic change (McCarthy et al. 2001). By assessing historical impacts of climatic change across the SW for specific landscape locations using the NRCS system of LRRs, MLRAs, and ecological sites the potential for negative impacts (vulnerabilities) can be estimated for some processes and properties of these systems, such as net primary production. For other processes and properties there is less certainty of negative impacts. The following list includes both vulnerabilities and sensitivities of rangeland livestock operations to climatic change across the SW region. This list of primary regional impacts is drawn from Elias et al. (2015). These impacts have specificity to rangeland beef cattle production in the Southwestern US, but are also more generic to any animal production system in the region. If the specific natures of each of these impacts are understood, there are conservation practices, management activities, and/or educational materials and trainings that can be employed to cope, in varying degrees, with their effects (Table 1).

\subsection{Reduced long-term livestock grazing capacities}

Inherently low long-term carrying capacities for rangeland livestock will be further reduced.

For example, the Clay Loam Upland ecological site within a 300-400 mm annual precipitation zone (NRCS ecological site reference \# R41XA109AZ; USDA 2014) is a common site within MLRA 41 of SE Arizona. Documented representative primary production level for this site is $\sim 1200 \mathrm{~kg} / \mathrm{ha} / \mathrm{yr}$. Drier, more arid conditions will likely result in primary production of $<560 \mathrm{~kg} / \mathrm{ha} / \mathrm{yr}$. This reduction in primary production could equate to a corresponding reduction of stocking rates of $\sim 20-40 \%$ or more (USDA 2014). Economic costs of livestock grazing operations are directly linked to forage production (Brownsey et al. 2013). Reductions in longterm average primary production will directly increase economic costs and further reduce the inherently low rates of return realized from rangeland livestock operations.

\subsection{Reduced air and water qualities}

Inherently low ground cover will be further reduced and increase site vulnerability to wind and/or water erosion. 


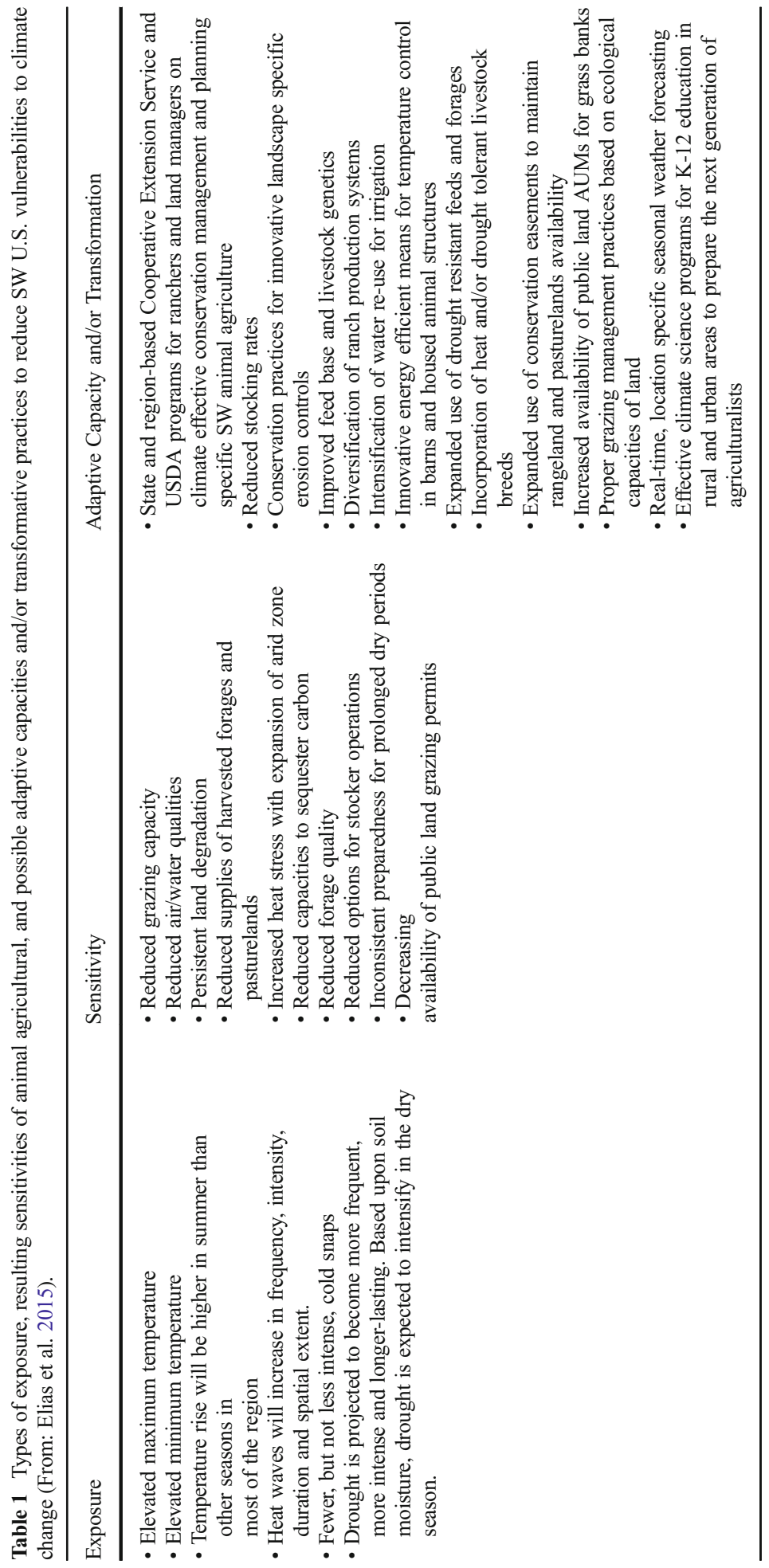


For example, a Granitic Loam ecological site dominated by creosote bush and native grasses (NRCS ecological site reference \# R030XB137CA; USDA 2014) is a common site within MLRA 30 in California. Representative annual production is $\sim 450 \mathrm{~kg} / \mathrm{ha} / \mathrm{yr}$ with ground cover of only $\sim 10-15 \%$ inherent to the site. Drier conditions will likely create a site with further reduced ground cover, even below $5 \%$. These sites are extremely susceptible to high rates of both wind and water erosion. A reduction in ground cover from 15 to $5 \%$ can triple the potential for soil loss by wind and water erosion (USDA 2014). For example, decreases in vegetation cover to $5 \%$ in a desert environment in California resulted in a $90 \%$ increase in sand flux, i.e., wind erosion losses (Lancaster and Baas 1998).

\subsection{Persistently degraded land health}

There will be an increased susceptibility to permanent degraded conditions.

For example, an Upland Loam ecological site dominated by Wyoming Big Sagebrush (NRCS ecological site reference \# R025XY314UT; USDA 2014) is a common site within MLRA 25 in Utah. This site is susceptible to degradation due to prolonged drought, fire and/or overgrazing. If vegetation on this site degrades from big sagebrush to yellow rabbit brush and invasive annuals, the degraded state is self-sustaining and can result in complete loss of site potential. These sites in degraded states have increased intervals of fire frequency and greatly reduced values for livestock grazing and as wildlife habitat, including for sage grouse. Restoration of these degraded states is extremely problematic (USDA 2014)

\subsection{Reduced supplies of harvested feeds and pasture forages}

The demand for non-rangeland forages will increase and overall supplies that are required in support of rangeland beef cow-calf production systems will likely be reduced.

The extensive nature of rangeland livestock production across the SW requires periods of supplemented feed and/or pasture forages (typically seeded forages harvested directly by grazing animals). Traditional livestock production is highly reliant on harvested forages, especially hay, that augment limited native forage supplies during drought, dormant seasons, or periods of exclusion such as during or after wildfires. Irrigated production of supplemented feeds and forages is prevalent across this region. However, only about $5 \%$ ( $\sim 0.4 \mathrm{M}$ ha) of the $\sim 8 \mathrm{M}$ ha of pasturelands in the SW were irrigated in 2012, a decline of about $0.2 \mathrm{M}$ ha since 2007 (USDA 2014). These pasturelands are primarily rain-fed (non-irrigated) and use of more drought tolerant improved forage species for these pasturelands is likely warranted. More frequent droughts may also contribute to a change in vegetation composition and reduction of ground cover, both of which can drastically increase susceptibility of ecological sites to water and wind erosion and reduce primary productivity (Polley et al. 2013; USDA 2014). If the current number of livestock are to be maintained within this LRR, they will likely need to be fed harvested or supplemental forages for longer periods with estimates ranging from 4 to $16 \%$ more supplemented feed under increased ambient temperatures (Mader et al. 2009).

\subsection{Increased heat stress associated with expansion of arid zones}

Arid sites within desert MLRAs (primarily within the Western Range and Irrigated Land Resource Region) may expand with projected changes in aridity and increased animal heat stress. 
Higher ambient air temperatures predicted across this arid region will further impact both soil moisture and potential evaporation rates. These impacts are areas of current research, but the resulting expansion of aridity is not yet well assessed or predicted. The direct negative impact of heat stress due to increased temperatures on resulting animal performance is well documented (St-Pierre et al. 2003).

\subsection{Further reduced capacities to sequester carbon}

An arid and semi-arid region already seriously limited in its inherent capacity to store carbon may be increasingly a source of atmospheric carbon.

Desert regions across the SW are periodic sources of atmospheric carbon during the year. However, uptake, or sequestration, of carbon is restricted to infrequent periods of significant precipitation that promote primary plant production. Overall carbon stores are quite low across this arid region, though highly influenced by vegetation type and amount. More arid conditions that may promote more woody species may increase carbon sequestration, even significantly (Petrie et al. 2015). Conversely, degradation resulting in annual grassland vegetation may lower carbon storage in soils and increase atmospheric carbon. Irrespective, carbon fluxes will continue to be low and volatile throughout the SW region (Bradley et al. 2006; Svejcar et al. 2008).

\subsection{Reduced forage quality}

Both harvested forages and rangeland forages may have increased cellulosic and lignin contents that reduce digestibility in ruminants.

In the SW, livestock production will be reduced by lower forage quality and quantity and a decrease in voluntary animal intake associated with lower forage quality, higher temperatures and heat stress. Even in the absence of the effects of increased greenhouse gas concentrations on climate patterns, atmospheric chemistry will increase the vulnerability of livestock operations (Polley et al. 2013). Forage quality (digestibility) will also decrease as a result of increased ambient temperatures (Craine et al. 2010). These declines in forage quality will result in reduced animal intake and lower animal performance (e.g., reduced daily weight gains). An emerging industry in the SW, grass-fed beef, may have to cope with decreased quality and quantity of forages as well as exploit animal genetics that are suited to more arid environments with greater presence of browse species (Estell et al. 2012).

\subsection{Reduced options for stocker cattle operations}

Beef cattle production in this region is reliant not only on cow-calf operations, but also on a declining acreage of pasturelands needed for stocker growth before entering the third phase of US beef production in feedlots.

Pastureland acreage in the SW Region has declined 20 \% between 2007 and 2012 (a reduction of $\sim 2 \mathrm{M}$ ha, excluding Arizona that lacks reported data) and the amount of irrigated pastureland has been reduced by $\sim 35 \%$ (USDA 2013). Stocker inventory has varied around 1.6 $\mathrm{M}$ head across the region since 2000), with approximately a $\sim 5 \%$ decline in annual inventory since 2007. This reflects reduced cow-calf inventories, and further reductions in irrigated pastureland. Reduced availability of pastures could further constrain opportunities for stocker operations and inventories. 


\subsection{Constraints on preparedness of ranching community for arid or drought conditions or rebuilding ranching operations following prolonged drought}

Even in environments where prolonged droughts are common, the ranching community may not be adequately prepared for the financial consequences and management requirements of conditions resulting from prolonged drought.

A recent survey of Utah ranchers who experienced drought in 1999-2004 and again in 2009 indicated that a large percentage $(67 \%)$ were either somewhat prepared or unprepared for the 2009 drought despite their prior experience with a prolonged 5-year drought ending in 2004. The average age of ranchers in the region is $\sim 58$ years old. Rebuilding livestock herds following droughts can be costly and can take years (Doye et al. 2012). Experiences in response to the recent prolonged drought in the Great Plains indicated that older producers may opt to sell out rather than rebuild their ranching operations following destocking in response to drought. This could lead to a generation shift in ranching to younger ranchers who may be less experienced but more progressive (Coppock 2011).

\subsection{Further reduction in the utilization of public land AUMs}

Continued increasing demands for ecosystem services other than food and fiber from public lands in the region will likely continue to reduce their use of public lands to supply forage.

Though the decline in BLM AUMs supplied within the SW region since 2004 depicted in Fig. 4 is slight, this decrease continues a constant decline throughout the 20th Century. Across the western US the billed AUMs from BLM lands have been in a steady decline since 1947 (USDI 2013). More specifically, for the five-state SW region the change in billed BLM AUMs has shown a similar precipitous decline from a high of 8.9 M AUMs before the 1950s drought to 3.7 M AUMs in 2012 (Fig. 4c). This steady decline in use of public land for livestock grazing, partly due to a reduced demand or a reduced capacity or both, represents an annual reduction in forage supply from public land of 30,000-50,000 AUMs. Conditions of these lands are highly variable, and it is unlikely public lands could even supply forage to meet increased demand, especially with more arid environmental conditions.

\section{Adaptive capacities}

This is a region that has supported animal agriculture since the late 16th Century when European settlers crossed the Rio Grande into present day west Texas and southern New Mexico with herds of cattle, sheep, goats and horses (Bowling 1942). For the past 4+ centuries the rangeland livestock industry, in its many forms and manifestations, has developed management strategies and conservation practices that impart resilience to common and often prolonged climatic extremes, especially droughts, which can seriously impact production from these animal agriculture systems (Havstad et al. 2006). A recent survey of rangeland grazing management practices in the West confirms rancher capacities to adopt grazing practices that impart resilience (Roche et al. 2015). The primary capacities of livestock production in the SW to adapt to increased ambient temperatures will continue to rely on these proven adaptive strategies (Joyce et al. 2013), such as reduced stocking rates, proper grazing management practices, erosion control conservation practices, diversified ranch income strategies, alternative forage supplies, practices that reduce heat stress, and accessing additional rangelands and pasture lands. Even though the aging demographics of western ranchers may increasingly be a 
deterrent to implementing any of these various adaptations because they may be unwilling to invest the needed time and capital, there are examples of creative management coalitions that are emerging in the SW that can serve as instructive management models (Brunson and Huntsinger 2008).

There are additional opportunities for incorporation of transformative practices and technologies that can sustain animal agriculture in the SW in more extremely variable and arid environments (Table 1). Transformations include effective incorporation of degraded water for irrigation, expanded production of drought tolerant feeds and forages, employing beef cattle genetics suited to either harsh and minimally productive forage environments or amenable to utilization of non-grass forages, land management partnerships, especially involving public lands, that create emergency supplies of forage during drought periods, development of realtime, site-based information applicable to individual ranches, and improvement of readily accessible weather forecasting capacities at temporal and spatial scales directly applicable to individual ranch operations (for examples, see: Anderson et al. 2015; Elias et al. In Review). Some of these transformative strategies have been developed and implemented for other regions of the world (Martin and Magne 2015; Moore and Ghahramani 2014) and could be adapted for application to the SW region.

Animal agriculture in the SW has shown a historical capacity to adapt and transform as needed to arid environments. Producers and land managers will need to thoroughly understand the vulnerabilities and sensitivities that face them as well as the ecological characteristics of their specific landscapes in order to cope with the emerging climatic changes across the SW region. However, there has been a tendency within this agricultural community to neither acknowledge localized threats of climatic change nor its anthropogenic causes (Prokopy et al. 2015). One of the purposes of the USDA Climate Hub network is to provide information to producers in efforts to overcome this resistance, where it exists. One reason the Climate Hub network has worked so closely in collaboration with the Agricultural Extension Service in many states is to link with partners, i.e., extension agents, who can reach the agricultural community as an accepted source of usable and practical information. This collaboration with state based Extension Service networks has been unique to the USDA Climate Hub network, and an intentional partnership designed to help overcome resistance to climate change information, where it exists. These historical capacities and collaborations will be critically important for further adaptation to the climatic changes that are now occurring and will continue to occur across this SW region.

Acknowledgments This work is a contribution of the SW Region Climate Hub of the USDA Risk Adaptation and Mitigation to Climate Change Network. Manuscript development was supported by the USDA, Agricultural Research Service, Rangeland Management Research Unit based at the Jornada Experimental Range with funding by the USDA (CRIS Project \# 3050-11210-007D) and the National Science Foundation (Grant DEB-0618210). Ryann Smith and Scott Schrader were critical to the development of illustrations and text preparation.

Open Access This article is distributed under the terms of the Creative Commons Attribution 4.0 International License (http://creativecommons.org/licenses/by/4.0/), which permits unrestricted use, distribution, and reproduction in any medium, provided you give appropriate credit to the original author(s) and the source, provide a link to the Creative Commons license, and indicate if changes were made.

\section{References}

Anderson DM, Estell RE, Gonzalez AL, Cibils AF, Torell LA (2015) Criollo cattle: heritage genetics for arid landscapes. Rangelands 37:62-67

Bowling GA (1942) Introduction of cattle into colonial North America. J Dairy Sci 25:129-154 
Bradley BA, Houghton RA, Mustard JF, Hamburg SP (2006) Invasive grass reduces aboveground carbon stocks in shrublands of the Western US. Glob Chang Biol 12:1815-1822. doi:10.1111/j.1365-2486.2006.01232.x

Brownsey P, Oviedo JL, Huntsinger L, Allen-Diaz B (2013) Historical forage productivity and cost of capital for cow-calf production in California. Rangel Ecol Manag 66:339-347. doi:10.2111/rem-d-11-00059.1

Brunson MW, Huntsinger L (2008) Ranching as a conservation strategy: Can old ranchers save the new west? Rangel Ecol Manag 61:137-147. doi:10.2111/07-063.1

Coppock DL (2011) Ranching and multiyear droughts in Utah: production impacts, risk perceptions, and changes in preparedness. Rangel Ecol Manag 64:607-618. doi:10.2111/REM-D-10-00113.1

Craine JM, Elmore AJ, Olson KC, Tolleson D (2010) Climate change and cattle nutritional stress. Glob Chang Biol 16:2901-2911. doi:10.1111/j.1365-2486.2009.02060.x

Doye D, Sahs R, Peel D (2012) Financing Herd Rebuilding After Drought-Induced Liquidations. Paper presented at the Agricultural \& Applied Economics Association's 2012 AAEA Annual Meeting, Seattle, Washington

Elias E, Steele C, Havstad K, Steenwerth K, Chambers J, Deswood H, Kerr A, Rango A, Schwartz M, Stine P, Steele R (2015) Southwest Regional Climate Hub and California Subsidiary Hub Assessment of Climate Change Vulnerability and Adaptation and Mitigation Strategies. United States Department of Agriculture, $76 \mathrm{pp}$

Estell R, Havstad K, Cibils A, Fredrickson E, Anderson D, Schrader T, James D (2012) Increasing shrub use by livestock in a world with less grass. Rangel Ecol Manag 65:553-562

Havstad KM, Fredrickson EL, Huenneke LF (2006) Grazing livestock management in an arid ecosystem. In: Havstad KM, Huenneke LF, Schlesinger WH (eds) Structure and function of a Chihuahuan desert ecosystem: the Jornada Basin long-term ecological research site. Oxford University Press, New York, pp 266-277

Huntsinger L, Bartolome JW (2014) Cows? In California? Rangelands and livestock in the Golden State. Rangelands 36:4-10. doi:10.2111/Rangelands-D-14-00019.1

Joyce LA, Briske DD, Brown JR, Polley HW, McCarl BA, Bailey DW (2013) Climate change and North American rangelands: assessment of mitigation and adaptation strategies. Rangel Ecol Manag 66:512-528. doi:10.2111/rem-d-12-00142.1

Lancaster N, Baas A (1998) Influence of vegetation cover on sand transport by wind: field studies at Owens Lake, California. Earth Surf Process Landf 23:69-82

Mader TL, Frank KL, Harrington J Jr, Hahn GL, Nienaber J (2009) Potential climate change effects on warmseason livestock production in the Great Plains. Clim Chang 97:529-541. doi:10.1007/s10584-009-9615-1

Martin G, Magne MA (2015) Agricultural diversity to increase adaptive capacity and reduce vulnerability of livestock systems against weather variability - A farm-scale simulation study. Agric Ecosyst Environ 199: 301-311. doi:10.1016/j.agee.2014.10.006

McCarthy JJ, Canziani OF, Leary NA, Dokken DJ, White KS (eds) (2001) Climate change 2001: impacts, adaptation, and vulnerability. Cambridge University Press, Cambridge

Moore AD, Ghahramani A (2014) Climate change and broadacre livestock production across southern Australia. 3. Adaptation options via livestock genetic improvement. Anim Prod Sci 54:111-124. doi:10.1071/AN13052

Peters DPC, Havstad KM, Archer SR, Sala OE (2015) Beyond desertification: new paradigms for dryland landscapes. Front Ecol Environ 13:4-12

Petrie MD, Collins SL, Swann AM, Ford PL (2015) Grassland to shrubland state transitions enhance carbon sequestraiton in the northern Chihuahuan Desert. Glob Chang Biol 21:1226-1235

Polley HW, Briske DD, Morgan JA, Wolter K, Bailey DW, Brown JR (2013) Climate change and North American rangelands: trends, projections, and implications. Rangel Ecol Manag 66:493-511. doi:10.2111 /REM-D-12-00068.1

Prokopy LS, Arbuckle JG, Barnes AP, Haden VR, Hogan A, Niles MT, Tyndall J (2015) Farmers and cliamte change: a cross-national comparison of beliefs and risk percetpions in high-income countries. Environ Manag 56:492-503

Reeves MC, Moreno A, Bagne K, Running S (2014) Estimating climate change effects on net primary production of rangelands in the United States. Clim Chang 126:429-442

Roche LM, Cutts BB, Derner JD, Lubell MN, Tatt KW (2015) On-ranch grazing strategies: context for rotaitonal grazing dilemma. Rangel Ecol Manag 68:248-256

Sayre NF, deBuys W, Bestelmeyer BT, Havstad KM (2012) The range problem after a century of range science: new research themes for altered landscapes. Rangel Ecol Manag 65:545-552

St-Pierre NR, Cobanov B, Schnitkey G (2003) Economic losses from heat stress by US livestock industries. J Dairy Sci 86:E52-E77. doi:10.3168/jds.S0022-0302(03)74040-5

Svejcar T, Angell R, Bradford JA, Dugas W, Emmerich W, Frank AB, Gilmanov T, Haferkamp M, Johnson DA, Mayeux H, Mielnick P, Morgan J, Saliendra NZ, Schuman GE, Sims PL, Snyder K (2008) Carbon fluxes on North American rangelands. Rangel Ecol Manag 61:465-474. doi:10.2111/07-108.1

Torell LA (2010) Economics of flexible versus conservative stocking strategies to manage climate variability risk. Rangel Ecol Manag 63:415-425 
USDA NRCS (1997) National range and pasture handbook. US Department of Agriculture, Grazing Lands Institute. 190-vi-NRPN. Washington, DC

USDA (2006) Land Resource Regions and Major Land Resource Areas of the United States, the Caribbean, and the Pacific Basin. US Department of Agriculture Handbook 296

USDA (2013) National Agricultural Statistics Service. Retrieved from http://www.nass.usda.gov. Accessed 15 Feb 2013

USDA (2014) Ecological site description system. Retrieved from http://esis.sc.egov/welcome/pgESDWelcome. aspx. Accessed 10 Nov 2014

USDI (2011) Bureau of Land Management letter to Permittees in Las Cruces grazing district. Bureau of Land Management, Las Cruces, NM, Field Office. Las Cruces, NM

USDI (2013) Authorized use of Bureau of Land Management administered grazing lands. Retrieved from 19471995: rangenet.org/tools/blmgrazing 1996-2012: www.blm.gov/public_land_statistics/index.htm Accessed 15 Jan 2013

USGS (2016) The national map small scale. http://nationalmap.gov/small_scale/atlasftp.html. Accessed 30 Mar 2016 